degrees must be significantly expanded. The rush toward parttime teachers must be ended and, instead, a sufficient cadre of full-time professors with appropriate career ladders appointed. Salaries must be sufficient to attract talented young scholars and to keep them in the profession.

In a differentiated academic system, not all professors will focus on research-typically the gold standard in terms of prestige and status. Most academics mainly teach, and their workloads should reflect this. It would also be impossible to return to the days of unfettered autonomy and little if any evaluation of academic work. Yet, accountability and assessment can be done in ways that are appropriate to academic work rather than punitive exercises.

If there is any good news in this story it is that more professors enjoy what they are doing and feel a loyalty to the profession. The I992 international Carnegie study of the academic profession found surprisingly high levels of satisfaction, and the 2007 Changing Academic Profession global survey found much the same result. Despite their problems, academic life has significant attractions. The challenge is to ensure that the academic profession is again seen by policymakers and the public as central to the success of higher education.

In the current environment, the popular press as well as some university administrators and many government officials are happy to criticize professors as the root of academe's problems. In fact, the opposite is the case-the professors are the root of the unprecedented success of higher education. There is always room for improvement, but professor bashing will lead to neither reform nor greater productivity.

\section{The Academic Profession: Colombia's 2019 Vision}

\section{IVÁn F. PACHECo}

Iván Pacheco was the Director of Quality Assurance for higher education in the Colombian Ministry of Education for more than three years. He is currently a doctoral student in higher education at Boston College. E-mail: ivan.pacheco.1@bc.edu.

$\mathrm{T}$ he emergence of the knowledge economy poses dramatic challenges for developing nations that have to struggle to insert themselves in a highly competitive market. Colombia's case illustrates this situation.

Colombia's government planning is focused on 2019, its 2ooth anniversary of independence. Policymakers concentrate on their country's movement into the knowledge economy as well as the role researchers and highly skilled workers play in that process. However, the country's current reality of academ- ic human capital will present a challenge in reaching this goal. Not enough high-quality researchers work in the higher education sector, in part because Colombia lacks the conditions to attract and retain talented academics.

Colombian teachers' salaries are not competitive in the international context, as illustrated in a recent study by the Boston College Center for International Higher Education, in which Colombia was ranked among the four lowest-paid countries within a group of $\mathrm{I} 6$. In addition, the country has not succeeded in developing alternative incentives to counterbalance the limited monetary rewards - such as, availability of good laboratories, supportive academic communities, and job stability. Although a few official documents have considered the importance of attracting foreign scholars, compensation and other mechanisms to retain local faculty and attract foreign tal ent have not yet been analyzed in depth. A picture of how faculty are hired and paid in Colombia illustrates the urgency for changes in its enrollment and remuneration structure.

\section{Colombian teachers' salaries are not competitive in} the international context,

\section{Compensation at Public and Private institutions}

The institution's nature (public or private) is perhaps the most relevant factor to explain how teachers are paid in Colombia. Among the 272 higher education institutions in the country only 8I are public, but they account for about 50 percent of the nation's enrollment.

Full-time and part-time teachers at public higher education institutions are considered public servants and are subject to special legal statutes. Faculty at private institutions, however, are subject to the general labor law applied to any other workers in the country.

To enter the academic track as a public employee, faculty must participate in a meritocratic process in which candidates' curriculum, academic productivity, and other elements are evaluated. A probation period can also be part of this process. Once the candidate is formally incorporated as a professor he or she will be tenured, under very similar conditions as for any other public employees in the country. Salaries are calculated based on a set of tables established by the central government, with little room for negotiation.

Two types of teachers at public higher education institutions are not considered public employees: the so-called occasional teachers and those hired through an hourly based contract, called profesores de hora cátredra. Conceived in the law as an exception, these two groups, usually referred to as "temporary teachers," are a significant portion of the total teaching personnel in the public sector-in 2005, representing 64 percent of Colombian higher education instructors, compared to only 25 percent of full-time teachers. 
Teachers at private universities usually do not possess tenure, and the majority are hired through contracts of less than a year. These contracts tend to be renewed, but an institution can decide not to renew a contract without notice or paying severance. As in public universities, teachers at private uni versities can be hired on hourly based contracts, part time or full time; other positions are also possible but less frequent. Private institutions possess greater flexibility to negotiate faculty salaries; for this and other reasons, salary information in private institutions is limited and difficult to study.

Teachers at private universities usually do not possess tenure, and the majority are hired through contracts of less than a year.

\section{FACULTY QUALIFICATIONS}

The minimum requirement to become a professor at a public university is a bachelor's degree. However, occasionally, people without such a degree are hired. There is no specific regulation on the minimum academic degree for private university faculty, but in general teachers have at least a bachelor's degree. Some exceptions may be found in technical institutions and programs associated with the arts. In 2005, about I.86 percent of Colombian higher education teachers had qualifications below a bachelor's degree; 36.7 percent had a bachelor's degree; and 6I percent had a postgraduate degree, including 3.3 percent holding a doctoral degree.

\section{LOOKING TOWARD 2019}

Colombia's development plan includes research and the production and application of knowledge as important components in most sectors. The draft of the education sector's 2019 strategic plan includes the goal of acquiring at least 30 percent of full-time-equivalent faculty with a doctoral degree, starting with a baseline of 8 percent of these teachers holding such a degree.

Colombia will have to create a flexible environment in public universities, improve faculty members' stability at public and private institutions, and consider competitiveness as a goal for researchers. Low salaries, precarious working conditions, and weak academic communities do not make a strong case to attract the best and the brightest to academe.

At present, just Io years away from 2019, the country should evaluate whether it will import foreign talent to improve its research capability. Given that salary plays an important role, the country should evaluate the convenience and viability of creating competitive salaries to attract Colombians and foreigners who have earned the desired qualifications to push the development plan forward. Faculty remuneration should be determined in light of the nation's vision and not only under the scope of the salaries' impact on the country's budget.

\section{Problems in China's Private Universities Osman Ozturgut}

Osman Ozturgut is the coordinator of advising and teacher certification, Division of Teaching and Learning, College of Education, University of Missouri-St. Louis, Saint Louis, Missouri, USA. E-mail: osmanhoca@hotmail.com.

A fter approval by the Beijing government, private universities began appearing in almost every major province in China. If obtaining any education is seen as the main goal, it would seem fair to say that these private colleges are providing great opportunities-given that they are accepting students with lower Chinese University Examinations scores and filling the enormous need for higher and continuing education in China. However, a focus on the quality of education (including facilities, equipment, and teaching and administrative staff) raises concern that the private colleges are not nearly as effective as even second-tier Chinese public universities.

Successful examples of private universities do exist in China (see Jing Lin and Ruth Hayhoe, "China's Private Universities: A Successful Case Study," International Higher Education, no. 5I) that are certainly providing high-quality education. However, these schools may be the exceptions, and today there are many more not-so-successful private universities in China. This article by no means intends to undermine the teaching and administration at effective institutions but attempts to provide a starting point for discussing the future of such private universities in China.

\section{INSTRUCTORS AND ADMINISTRATORS}

The instructors at private universities mainly constitute younger faculty members with bachelor's degrees and limited teaching experience. They teach 16 to 20 hours a week, with the remaining time left for chatting with other instructors, given the absence of research or professional development opportunities. The instructors usually stay at these institutions for only one or two semesters before moving on to their "real" jobs at public universities. They are paid an average salary of 2,500 RMB (around \$US350) a month and are provided a studio apartment on campus. While they pay their instructors salaries similar to those of private universities, public universities also provide job security and prestige.

The top management of the private institutions includes 